Sergey Stelnikovich (Сергей Стельникович)

Uniwersytet Państwowy im. Iwana Franki w Żytomierzu (Ukraina)

ORCID ID: 0000-0001-9121-8977
OBLICZA WOJNY

TOM 5 - MIASTO I WOJNA

ŁóDŹ2021 •ISBN 978-83-8220-699-9• •. 243-257

https://doi.org/10.18778/8220-699-9.14

\title{
ГОРОДСКОЕ НАСЕЛЕНИЕ И НАЦИСТСКАЯ ПРОПАГАНДА В ГОДЫ ВТОРОЙ МИРОВОЙ ВОЙНЫ (НА ПРИМЕРЕ ГОРОДОВ ЖИТОМИРСКОЙ ОБЛАСТИ)
}

\begin{abstract}
Streszczenie. Naziści systematycznie oddziaływali propagandowo na ludność okupowanej Ukrainy. Nazistowska propaganda była aktywna również wśród mieszkańców miejskiego obwodu żytomierskiego. Ten region ze względu na szereg cech zajmował jedno z centralnych miejsc w polityce okupacyjnej Niemiec. W pobliżu Żytomierza znajdowała się kwatera Heinricha Himmlera oraz powstały kolonie niemieckie Hegewald i Forsterstadt. Region odznaczał się też wieloetniczną ludnością i aktywnym ruchem oporu. Gazety, radio, kroniki filmowe i ulotki stały się głównym narzędziem propagandy nazistowskiej wśród ludności miejskiej obwodu żytomierskiego. Hitlerowcy prowadzili przede wszystkim antyradziecką propagandę wśród mieszkańców miast regionu. Przejawiało się to m.in. niszczeniem zabytków i zmianą nazw niektórych osad związanych z okresem sowieckim. W samych miastach zmieniono nazwę szeregu „radzieckich” ulic, placów i alejek. Od drugiej połowy 1943 r. ekshumacja ofiar NKWD z Winnicy stała się głównym wątkiem antyradzieckiej kampanii propagandowej. Dla nazistów szczególne znaczenie miała propaganda antyżydowska, gdyż niektóre miasta obwodu żytomierskiego ( $w$ tym Berdyczów) były w okresie przedwojennym ośrodkami kultury żydowskiej. Propaganda antyżydowska wśród ludności miejskiej miała charakter systemowy i często łączyła się z antyradzieckimi kampaniami propagandowymi. Ważnym obszarem nazistowskiej propagandy w czasie drugiej wojny światowej wśród miejskiej ludności regionu były akcje wspierające politykę okupacyjną i promujące okupacyjny porządek.
\end{abstract}

Słowa kluczowe: obwód żytomierski, okupacja hitlerowska, propaganda, ludność miejska, prasa

В годы Второй мировой войны местное население, в том числе городское, оккупированной нацистами территории Украины находимось под постоянным пропагандистским воздействием. Пропагандистские кампании прежде всего направцялись на перманентную подАержку антисоветских 
настроений и на необходимость выполнения оккупационных распоряжений. Важное значение нацисты надаваци и антиеврейской пропагандистской кампании, которая нередко была связана с антисоветской. Особые пропагандистские мероприятия проводились среди населения городов Житомирской области. Ведь этот регион в сику ряда особенностей занял одно из центрацьных мест в нацистской политике на занятой территории СССР (размещение вблизи Житомира ставки Генриха Гиммлера, наличие немецких колоний ГегевацьА и ФьорстерштаАт, полиэтнический состав населения, активная деятельность движения сопротивления и т. А.).

ААминистративно территория Житомирской области (находимась в условиях нацистской оккупации с июля 1941 г. по март 1944 г.) была вкцючена в состав Генерацьного округа Житомир Райхскомиссариата Украина. Сюда также входими территории центрально-северной части Винницкой области Украины и большая часть Полесской (ныне - в составе Гомемьской) области Белоруссии. Среди крупнейших городов Житомирской области выдемямись Житомир, Бердичев, Коростень, Новоград-Волынский (Звягель), Коростышев, Радомышль, Овруч. В регионе быми и небольшие города и местечка, как: Мамин, Ружин, Олевск, Красноармейск (Пулины), Володарск-Волынский (Горошки), Азержинск (Романов), Чуднов, Мархиевск (Аовбыш) и др.

В институционацьном отношении пропагандистские кампании на оккупированной территории Украины проводимись „восточным” отделом Министерства пропаганды Третьего Райха, отделом пропаганды Верховного командования Вермахта, Управцением прессы и пропаганды Министерства оккупированных восточных территорий, некоторыми отдемами Министерства иностранных дел нацистской Германии и т. А. ${ }^{1}$ С утверждением гражданской администрации пропаганду на местах также проводили структуры Райхскомиссариата Украина. Это - отдел общей пропаганды политического управления с подотделами пропаганды, радио, прессы, кино, иностранных связей, хозяйственной вербовки, выставочный, обслуживания войск². На местах пропагандистские кампании также прово-

${ }^{1}$ М. МихАЙлЮК, Німецька пропаганда в Украйні, [в:] Україна в Аругій світовій війні. Погляд з ХХІ ст. Історичні нариси. Кн. 1, реА. О. АИСЕНКО, Київ 2010, с. 645.

2 П. Рекотов, Органи управління на окупованій території України (1941-1944рр.), „Український історичний журнал” 1997, № 3, с. 93. 
Аими отделы генерацьных комиссариатов, среди которых главный отдем агитации и пропаганды генерацьного комиссариата Генерацьного округа Житомир ${ }^{3}$. Также отметим, что до утверждения нацистской гражданской власти, в середине июля 1941 г. в Житомире по инициативе Вермахта было создано Житомирское областное управцение как орган украинского вспомогательного управления. В его структуре выделя ся отдел пропаганды ${ }^{4}$.

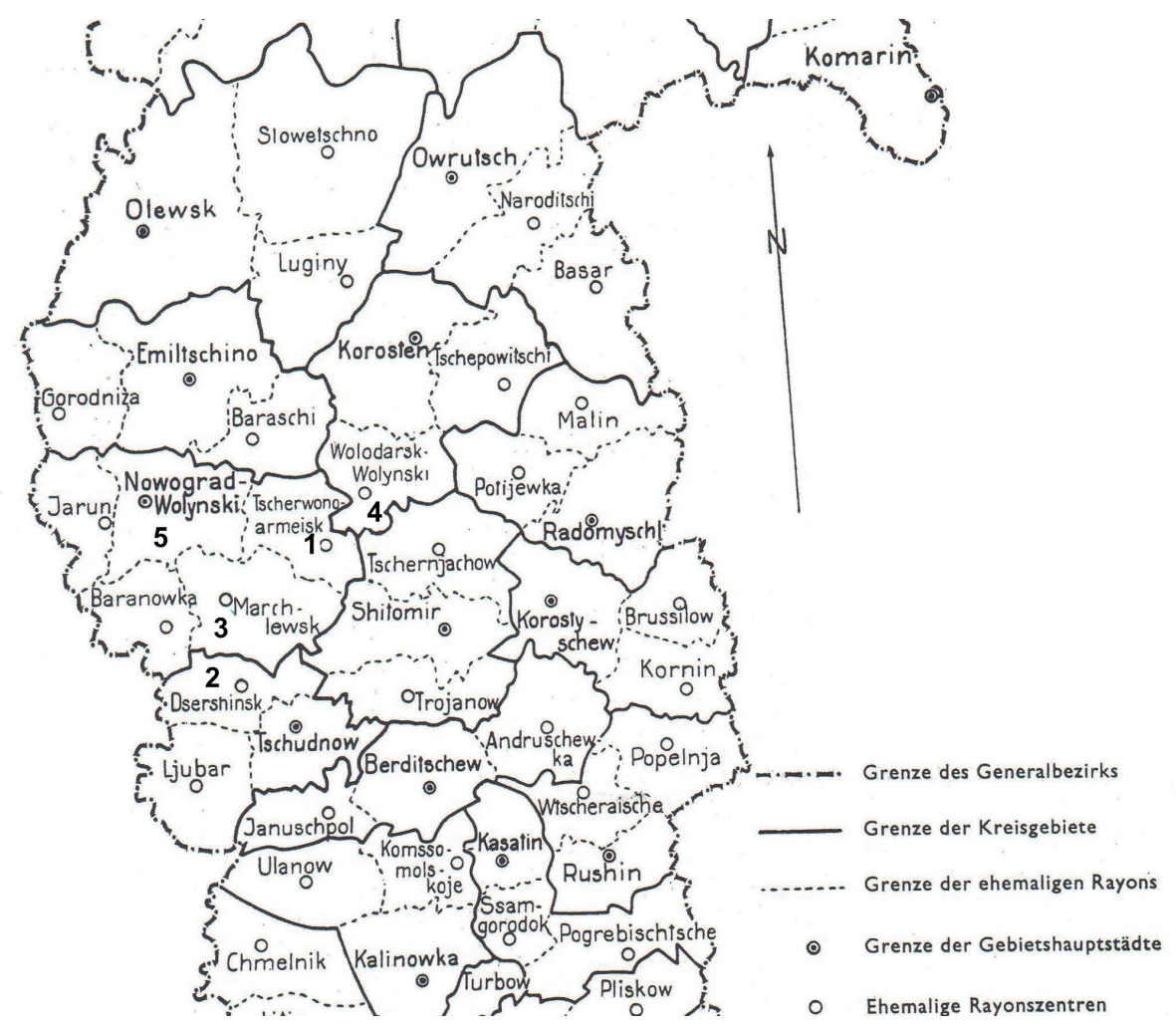

Рис. 1. Фрагмент немецкой карты Генерального округа Житомир с Житомирской областью (ГАЖО, ф. Р-1151, оп. 1, д. 50, л. 23). Во время нацистской оккупации в Житомирском регионе постановлениями областного управления были переименованы города (обозначены цифрами): 1. Красноармейск (Krasnoarmeisk, Tscherwonoarmeisk) - на Пулины, 2. Дзержинск (Dsershinsk) - на Романов, 3. Мархлевск (Marchlewsk) - на Довбыш, 4. Володарск-Волынский (Wolodarsk-Wolynski) - на Горошки, 5. Новоград-Волынский (Nowograd-Wolynski) - на Звягель

${ }^{3}$ Государственный архив Житомирской области (Аалее: ГАЖО), фонд (ф.) Р-1151, опись (оп.) 1 , дело (А.) 32, с. 3.

${ }^{4}$ Центральный государственный архив высших органов власти и управления Украины (Аалее: ЦГАВОВУ Украины), фонА (ф.) 3959, опись (оп.) 2, демо (А.) 50, с. 51-53. 
В результате деятельности различных пропагандистских органов в городах Житомирской области в годы нацистской оккупации быма создана сеть периодических изданий, организовано радио и кинопропаганду, Аругие средства пропаганды (Аистовки, плакаты и т. А.). Центральное информационно-пропагандистское значение имели украиноязычные газетные издания, выходившие в Житомире („Гомос Вомыни”), Бердичеве („Новая эпоха”), Коростышеве („Коростышевские вести”), Звягеле („Звягеньское слово”), Олевске („Олевские вести”), Овруче („Овручские вести”), Ружине („Ружинский вестник”), Чуднове („Освобожденная Украина”)5. В начаме нацистской оккупации в Житомире, как бывшем областном центре, возобновимась деятельность советского радиоузма, $и$ иия радиосети, громкоговорителей и индивидуальных радиоточек 6 . Также в первые месяцы оккупации в городах была организована сеть кинотеатров. Аемонстрируемые здесь фимьмы и кинохроника, помимо прочего, отмечацись высокой степенью пропаганды. Наряду с пропагандистским значением газеты, радио, кинохроника (так называемые „недемьные обзоры”, которые демонстрировацась перед показом художественных фимьмов) должны были донести до городского населения распоряжение оккупационных в $а$ астей.

Как отмеча ось, центрацьное место в нацистской пропаганде среди городского населения занимала антисоветская пропаганда, которая часто строицась на основе обращений к большевистским преступ ениям довоенного времени. В связи с этим распространенным стало уничтожение внешних признаков советской в асти (памятников, изменение названий городов, городских улиц, площадей, переулков). Уже в течении первых месяцев оккупации в городах Житомирской области практически полностью были демонтированы все большевистские памятники. После вступления в тот или иной населенный пункт немецкие военные выступами инициаторами такого демонтажа, который, как правимо, сводился к обычному физическому уничтожению образцов советской монументальной пропаганды. Напр., в Житомире уже в начаме оккупации были разрушены памятники ВАадимиру Аенину, Феликсу Азержинскому,

\footnotetext{
5 ЦГАВОВУ Украины, ф. 3206, оп. 2, А. 88, с. 1-42.

${ }^{6}$ ГАЖО, ф. П-1376, оп. 1, А. 31, с. 1-2.
} 
Николаю Щорсу, большевистской революциит. В Аругих городах Житомирской обцасти до войны в основном были установлены памятники ВАадимиру $е$ енину, которые также демонтироваци ${ }^{8}$. Необходимо отметить, что такие действия немцев не вызывали возражений среди местного насемения. Аیя него памятники партийно-советских активистов ассоциировались с антиукраинской политикой большевиков довоенного времени. Поэтому мещане нередко сами приобщались к демонтажу большевистских монументов.

С целью поддержания антисоветских настроений в первые месяцы нацистской оккупации состоялись переименования городов, которые напоминали большевистские реалии и были введены в межвоенный период. В данном случае такая инициатива поддерживалась украинской вспомогательной администрацией - Житомирским областным управлением. При изменении „советских” названий городов в основном возвращались исторические топонимы. Согласно постановцению Житомирского областного управления от 8 августа 1941 г. г. Красноармейск было возвращено историческое название г. Пулины; г. Азержинск бым переименован в г. Романов 9 . Постановцение областной вспомогательной администрации от 14 августа 1941 г. предусматривало переименование г. Мархиевск на г. Аовбыш, г. Володарск-Волынский - на г. Горошки ${ }^{10}$. Отметим, что в годы Второй мировой войны официально было изменено и название г. НовограА-Волынский, которое использовалось еще с 1795 г., со времен Российской империи. Городу бымо возвращено историческое название - Звягель.

По-Аругому сложикась ситуация с переименованием улиц (пмощадей, переулков) в городах Житомирской области. Вместе с возвращением исторических названий „советским” улицам (площаАям, переулкам) ввоАились и новые названия, связанные с украинскими реалиями и с именами политической и военной элиты нацистской Германии. Часть новых топонимов была идеологически нейтральной. В частности, к концу 1941 г. в Бердичеве, кроме других, были переименованы улицы

7 ГАЖО, ф. Р-2636, оп. 1, А. 52, с. 269.

8 ГАЖО, ф. Р-2636, оп. 1, А. 17, с. 130.

9 ГАЖО, ф. Р-1156, оп. 1, А. 3, с. 484.

10 „Українське слово”, Житомир 1941, 17 серпня, с. 4. 
(пмощади, переулки): Героев Перекопа (пер. Сечевых Стрельцов), Красной Авиации (ум. Бродецкая), Парижской коммуны (ум. 5-я Украинская), Октябрьская (ум. 2-я Украинская), Петровского (ук. 1-я Украинская), Куйбышева (ум. Под тихими ивами), 8-го Марта (ул. Аиповая), Кагановича (уц. Хозяйственная), Советская (ул. Волынская), Щорса (ул. Потопольская), Энгельса (ул. Пашковская), Совплощадь (Украинская площадь), Котовского (ул. Моховая), Фрунзе (уц. Ааниловская), Коминтерна (ул. Садовая $)^{11}$. В свою очередь, нацистские названия улиц должны были пропагандировать новые оккупационные реалии. В общем, таких улиц было относительно немного. В регионе новые „немецкие” названия улиц появились в Житомире как аАминистративном центре генерального округа. 3Аесь ул. Карла Маркса была переименована в ул. Гитлера, ум. Городского

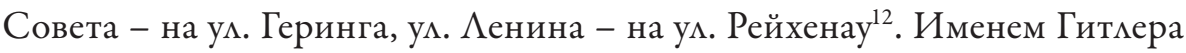
также была названа одна из улиц в г. Коростышев ${ }^{13}$. ОАнако, усимение оккупационной политики привело к „непопулярности” нацистских названий улиц, в частности в Житомире. В связи с этим гражданская администрация их переименовала: ул. Гитлера на ул. ГАавную, ул. Геринга на ум. Малую Коростенскую, ул. Рейхенау на ум. Киевскую.

Аیя подАержания среди горожан постоянных антисоветских настроений оккупационная вцасть систематически размеща а антисоветские пубцикации в периодике, сообщения на радио, распространяла соответствующие Аистовки и т. А. При этом достаточно часто антисоветская пропаганда была связана с антиеврейской пропагандой нацистов.

В середине 1943 г. в условиях отступления Вермахта на Восточном фронте и усимения антинемецких настроений оккупационные органы решили активизировать антисоветскую пропаганду. Аля этого было решено использовать эксгумацию и перезахоронение жертв винницкого НКВА Аовоенного времени. Не послеАней причиной такого решения стал успех пропагандистской кампании по выявлению в апреле 1943 г. тел жертв Катынского расстрела весны 1940 г. Также, акцентируя внимание на большевистских преступлениях, нацисты пытались отвлечь внимание от собственных змодеяний. Нацистская пропагандистская

\footnotetext{
11 „Нова доба”, Бердичів 1941, 5 грудня, с. 4.

12 Г. Мокрицький, Вулиці Житомира, Житомир 2007, с. 93, 156.

13 ГАЖО, ф. Р-1568, оп. 1, А. 3, с. 6.
} 
кампания, связанная с эксгумацией жертв винницкого НКВА, прежде всего быма направлена на местное насемение оккупированных нацистами украинских территорий; ей также пытались придать международный резонанс.

События, связанные с эксгумацией и перезахоронением жертв коммунистического террора в Виннице, широко освеща ась в официальной периодике Житомирской обцасти. В житомирской газете „Голос Вомыни” об этих событиях пропаганда писаца так:

Большевизм в Украине - это систематическое нравственное и духовное, а в первую очередь бандитское физическое уничтожение украинцев. Около Винницы разрыто могимы. Горы, непроглядные горы трупов. На известие об этом жалобно встрепенется каждое украинское сердце. Сколько матерей, женщин и детей ищут там свои родных. Там весь украинский народ ищет тленные останки святых мучеников украинских митрополитов, епископов, священников. Там в тех могиках мы ищем наших ученых, поэтов, художников, музыкантов ${ }^{14}$.

Аополнительными формами этой антисоветской пропаганды стало распространение пропагандистских $\Lambda$ истовок ${ }^{15}$, книжной продукции; в городах региона также демонстрировацась тематическая немецкая кинохроника ${ }^{16}$. Между Житомиром и Винницей Аля перевозки насемения к местам эксгумации с 4 августа 1943 г. бым открыт специа ьный автобусный маршрут ${ }^{17}$, который на пути к Виннице проходим через Бердичев. Об одной из таких поездок из Бердичева в Винницу рассказывала в послевоенное время советская активистка Евгения Огневюк:

Весной 1943 г. в Винницком парке раскопаци много могиц, о которых немцы писали в своих газетах, что будто эти могимы наполнены жертвами НКВА. Я поинтересовацась этими раскопками и поехала в Винницу. КогАа я пришла в Винницкий парк, то увидема очень много трупов в могилах. НаА могицами стояни Аюди и оплакиваци своих погибших родных ${ }^{18}$.

\footnotetext{
14 „Голос Волині”, Житомир 1943, 9 мипня, с. 3.

15 ГАЖО, Аистовки 995/123, с. 94.

16 Центральный государственный кинофотофоноархив Украины имени Г.С. Пшеничного (Аалее: ЦГКФФА Украины имени Г.С. Пшеничного), № 3255.

17 „Голос Волині”, Житомир 1943, 4 вересня, с. 4.

${ }^{18}$ ГАЖО, ф. Р-2636, оп. 1, А. 9, с. 41.
} 
С антисоветской пропагандистской цемью оккупационные органы Аопускаци установление в городах мокацьных антибольшевистских памятников. В начаце оккупации немецкая аАминистрация подАержала просьбу населения г. Пулины по установлению памятника жертвам антибольшевистского восстания 1919 г. под руководством атамана Соколовского ${ }^{19}$. ОАнако, видимо, через определенные организационные моменты (отсутствие среАств, стройматериалов) этот монумент не бым завершен. В сентябре 1943 г. в г. Овруч у разрушенной большевиками церкви был установлен крест как символический памятник украинцам, уничтоженным и депортированным НКВА. Во время открытия памятника присутствоваци более

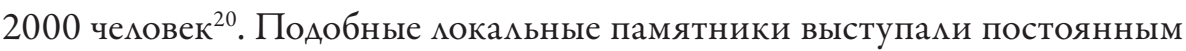
источником подАержки антисоветских настроений.

Особое значение Аця нацистов имела антиеврейская пропаганда. Ведь именно ряд городов Житомирской области, среди которых Бердичев, в Аовоенное время были центрами еврейской культуры. Регион стац одним из первых на территории Райхскомиссариата Украина, где зафиксированы массовые уничтожения евреев. Антиеврейская пропаганда среди городского населения имела системный характер и часто накмадывалась на антисоветские пропагандистские кампании. Оккупационные пропаганАистские органы отождествцяли довоенные большевистские преступ ения с действиями евреев и распространими тезис о „жидо-большевизме”.

Антиеврейские кампании распространимись и в печатной пропаганде, и на радио, в кинопропаганде, в том числе в художественных фильмах, которые демонстрировацись в городских кинотеатрах региона. Среди показательных кинокартин - фимьм „РотшимьА” производства немецкой киностудии „UFA”. В своеобразной рецензии на фимьм, размещенной в житомирской газете „Голос Волыни”, в духе нацистской пропаганды отмечено:

Сюжетом фимьма явцяется историческая разведка в прошлое Европы, которую буквально завоевываци евреи, коварными методами превращая европейский континент в плацдарм своих Аействий, пытаясь использовать Европу, закрепостить ее, а европейские народы превратить в рабов ${ }^{21}$.

\footnotetext{
19 „Голос Волині”, Житомир 1942, 6 червня, с. 4.

20 „Овручські вісті”, Овруч 1943, 11 вересня, с. 4.

21 „Голос Волині”, Житомир 1941, 11 грудня, с. 4.
} 
Такой подход нацистской пропаганды, в частности в начале оккупации, прежАе всего предусматривац усимение антиеврейских настроений и провоцирование антиеврейских выступлений, чего, все-таки, в полной мере достичь не удалось. По крайней мере, в городах Житомирской обмасти скучаи еврейских погромов в начале нацистской оккупации были редкостью. В то же время антиеврейская пропаганда, на смотря на фактическую расправу нацистов наА евреями региона в течение конца кета - осени 1941 г., продолжалась до последних Аней нацистского присутствия. Она особенно активизировацись в печатной пропаганде региона (в газетах, Аистовках) второй половины 1943 г. в рамках освещения нацистской эксгумации жертв винницкого НКВА. Исследовательница этого вопроса Венди $\Lambda$ ауэр (Vendi Lauer), ссымаясь на историка Амира Вайнера (Amir Vayner), утверждает, что

Ааже после того, как немцы убими почти каждого еврея в регионе, они и дальше продолжаци использовать идеи антисемитизма как действенную мобимизующую силу против большевизма. (...) после почти трех мет нацистской антисемитской практики и пропаганды мало кто противился или ставил под сомнение такие гротескные, но искусные искажения. Аействительно, во время войны немцы раздули тлеющую этническую вражду и предложили новые формы антисемитизма в Житомире (и в остальной Европе) $)^{22}$.

ОАнако, считаем, что антиеврейская пропаганда нацистов даже на завершающем этапе войны прежде всего быма обусловлена их расистскими теориями и ростом употребцения стереотипного тезиса о „жидо-большевизме” в связи с усимением антисоветской пропаганды.

ОАним из направлений нацистской пропаганды среди городского населения Житомирской области стаци кампании, направленные на подАержку политики оккупационной аАминистрации, прежде всего выполнения разцичного рода распоряжений. В этом случае оккупационная пропаганда между населением городов и сел мало отлича-

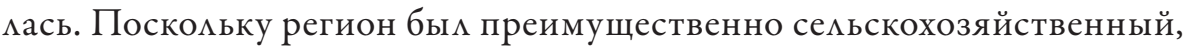
среди мещан распространялась пропаганда поддержки сельскохозяйственной инициативы. МежАу прочим, промышленность региона

22 W. LOWER, Nazi Empire Building and the Holocaust in Ukraine, Chapel Hill 2005, s. 195. 
(в основном пищевая и мегкая) в годы нацистской оккупации, распространена в городах, также в значительной степени зависела от сельского хозяйства.

Уже с весны 1942 г. в городах распространимись призывы Аля отправки горожан на сезонные сельскохозяйственные работы на юге Райхскомиссариата Украина ${ }^{23}$. В пропаганде нацистов жители городов Житомирского региона воспринимацись как помощь семьскому населению в период сбора урожая, особенно в 1943 г., когда значите ьная часть крестьян была депортирована на работы в Райх. В это время Аля сбора урожая оккупационные органы активно призываци не только городское население, но и детей. В одной из соответствующих пропагандистских публикаций отмечамось:

И поэтому горячие Ани жатвы будут также горячими Анями труда всех, кто находится в Украине. Кроме крестьянства на жатву с серпами в руках и с жаром в душе пойдут также жители города - рабочие, ремесленники, служащие и школьники. (...) Пора всем украинским матерям, родителям и детям города и села отправиться в поле $\mathrm{e}^{24}$.

При этом отмечалось, что от степени участия горожан в выполнении тех или иных видов работ, в том числе сельскохозяйственных, будет зависеть их продовольственное обеспечение.

Пропаганда всячески подчеркивала, что развитие украинского сельского хозяйства Аолжно происходить поА „прогрессивным” немецким руководством и контролем. С этой же целью нацисты провели в г. Радомышиь сельскохозяйственную выставку, которая Аолжна была наглядно показать „новые пути к улучшению семьского хозяйства в разных его участках" под немецким руководством. Выставка стаца важным сюжетом кинохроники нацистов, которая демонстрировацась в пределах всей оккупированной Украины ${ }^{25}$.

Особое место среди горожан занимама пропаганда работ в Германии. Благодаря пропагандистским призывам первый добровольный отъезд жителей отдельных городов региона, в частности Житомира, состоялся

\footnotetext{
23 „Нова доба”, Бердичів 1942, 4 березня, с. 4.

24 „Голос Волині”, Житомир 1943, 17 мипня, с. 4.

25 ЦГКФФА Украины имени Г.С. Пшеничного, № 3273.
} 
уже в январе 1942 г. ${ }^{26} \mathrm{C}$ весны 1942 г. пропагандистские кампании по набору рабочей симы усимимись, но не приносими желаемого результата. Ведь описаны пропагандой реации пребывания в Германии противоречими реацьной практике массовых депортаций и условиям пребывания в Райхе. Аля усиления этого направления пропаганды появилась новая форма агитации - публикация писем (открыток) якобы от имени остарбайтеров, где последние положительно отзывались об условиях труда, проживания и досуга в Германии. В качестве примера такой пропаганды можно процитировать письмо, опубмикованное в одной из местных газет, Анны Аавренчук к своим родителям в г. Горошки:

Живу я хорошо, я уже Вам описываца несколько раз. Нового у меня ничего
нет; работаю я у майора, жена его очень хорошая, я сейчас не голая и не бо-
сая; хозяйка дала мне 6 платьев, 2 пары ботиноки одни заказаца Аля пошива.
Питание очень хорошее, работа мегкая. В моей госпожи есть 4 велосипеда
и я уже умею ездить и езжу, куда меня посылают ${ }^{27}$.

Привлечь молодежь на работы в Германию должна была и радиопропаганда, которая, как отмечалось, распространилась преимущественно в Житомире как бывшем областном центре, она также достигаца окружающих сел. В определенной степени радиопропаганда с 1943 г. была представлена и в отдельных провинциальных городах. Начиная с июля 1943 г. по воскресеньям на украинском и русском языках транслироваАись тематические пропагандистские радиопередачи ${ }^{28}$.

Аля привлечения рабочих в Райх, в том числе со среды городского населения, пропагандировался немецкий образ жизни. Наряду с традиционными формами пропаганды (газеты, $и$ истовки, радио, кинопропаганда и т. А.) Аля этого в Германию периодически отправ ялись „репрезентатив-

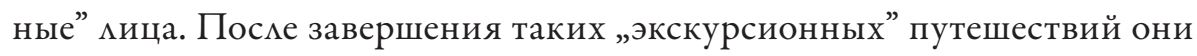
активно вкцючацись в соответствующую пропаганду. Уже с 1942 г. такие путешествия преимущественно организовывацись Аһя крестьян (преАседателей общественных хозяйств). В октябре 1943 г. к ним присоединимись городские жители, среди которых представители образовательной

\footnotetext{
26 „Голос Волині”, Житомир 1942, 7 січня, с. 4.

27 „Голос Волині”, Житомир 1943, 26 жовтня, с. 3.

28 „Голос Волині”, Житомир 1943, 3 мипня, с. 4.
} 
и журналистской сфер. После завершения поезАки часть из них с пропагандистскими речами выступима на житомирском радио ${ }^{29}$.

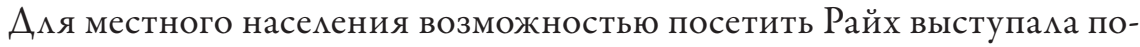
беда в объявленном генерацьным комиссаром Генерацьного округа Житомир Эрнстом Аейзером (Ernst Leyzer) в марте 1943 г. конкурсе в прессе на темы „За что мы благодарны немцам?” и „Никогда не быть большевизму”. Немецкий администратор в качестве вознаграждения победитеАям предлагац посетить Германию на 10-14 Аней ${ }^{30}$. В Аанном случае уже сам конкурс воспринимался как важное пропагандистское мероприятие. Ведь здесь пропаганда нацистских реалий через прессу проводимась усимиями самого местного населения. Такие „конкурсные” статьи с весны 1943 г. в разных газетных изданиях региона стаци достаточно распространенными ${ }^{31}$.

В свою очередь, советские органы с целью влияния на настроения населения оккупированных нацистами территорий проводими контрпропагандистские мероприятия. Это происходимо посредством распространения советских газет и Аистовок, слухов (пропаганда „шепотом”). Напр., в районе Бердичева распространились инициированные советской пропагандой слухи, что со временем все украинцы и поляки будут носить на рукавах повязки с определенными пометками, а после евреев немцами будут уничтожены все поляки. Также благодаря советской пропаганде в Бердичеве распространимись слухи о симьном голоде в Германии. Такая советская пропаганда значительно усложнима набор рабочей силы в Бердичеве Аля отправки в Райх. ВАияние разного рода слухов в районе Бердичева был настолько значительным, что осенью 1942 г. сотрудники кожевенного завода города прекратили работу, опираясь на то, что больше нет никакого смысла работать ${ }^{32}$. Особенно значительное влияние советской пропаганды ощущалось в городах севера Житомирской области (Овруч, Олевск), где были достаточно симьными позиции советского Авижения сопротивцения.

\footnotetext{
29 Архив Управления Службы безопасности Украины в Житомирской области, фонд 6, Аело 30338, листы 26-28.

30 ГАЖО, ф. Р-1151, оп. 1, А. 137, м. 17; W. LOWER, op. cit., s. 194.

31 „Звягельське слово”, Звягень 1943, 10 мипня, с. 3; „Олевські вісті”, Олевськ 1943, 17 мипня, c. $2-3$.

${ }^{32}$ ЦГАВОВУ Украины, ф. 4328, оп. 1, А. 2, с. 108.
} 
Таким образом, в годы Второй мировой войны городское население Житомирской области находимось под постоянным пропагандистским воздействием нацистской оккупационной вцасти. Через газеты, радио, кинопропаганду, Аистовки и т. А. нацисты пыталась постоянно подАерживать антисоветские и распространять антиеврейские настроения среди населения, скмонить его к выполнению оккупационных распоряжений. В то же время наблюдалось частое сочетание антисоветской и антиеврейской пропагандистских кампаний нацистов.

\section{BIBLIOGRAFIA}

\section{Źródła archiwalne}

Архив Управления Службы безопасности Украины в Житомирской области, фонА 6, Аемо 30338, мисты 26-28 (Arkhiv Upravleniya Sluzhby bezopasnosti Ukrainy v Zhitomirskoy oblasti, fond 6, delo 30338, listy 26-28).

Государственный архив Житомирской области, (Gosudarstvennyy arkhiv Zhitomirskoy oblasti): фонА (ф.) П-1376, опись (оп.) 1, дено (А.) 31 - fond (f.) P-1376, opis' (op.) 1, delo (d.) 31); ф. P-1151, оп. 1, A. 32 (f. R-1151, op. 1, d. 32); ф. P-1151, оп. 1, А. 137 (f. R-1151, op. 1, d. 137); ф. P-1156, оп. 1, A. 3 (f. R-1156, op. 1, d. 3); ф. P-1568, оп. 1, А. 3 (f. R-1568, op. 1, d. 3); ф. P-2636, оп. 1, А. 9 (f. R-2636, op. 1, d. 9); ф. P-2636, оп. 1, А. 17 (f. R-2636, op. 1, d. 17); ф. Р-2636, оп. 1, А. 52 (f. R-2636, op. 1, d. 52); мистовки 995/123 (listovki 995/123).

Центральный государственный архив высших органов власти и управления Украины (Tsentral'nyy gosudarstvennyy arkhiv vysshikh organovvlasti i upravleniya Ukrainy): фона (ф.) 3206, опись (оп.) 2, дело (А.) 88) - fond (f.) 3206, opis' (ор.) 2, delo (d.) 88; ф. 3959, оп. 2, А. 50 (f. 3959, op. 2, d. 50); ф. 4328, оп. 1, А. 2 (f. 4328, op. 1, d. 2).

Центральный государственный кинофотофоноархив Украины имени Г.С. Пшеничного (Tsentral'nyy gosudarstvennyy Kinofotofonoarkhivukrainy imeni G.S. Pshenichnogo): фона 3255, 3273 (f. 3255, 3273).

\section{Prasa}

„Голос Волині”, Житомир 1941, 11 грудня („Holos Volyni”, Zhytomyr 1941, 11 hrudnya). „Голос Волині”, Житомир 1942, 7 січня („Holos Volyni”, Zhytomyr 1942, 7 sichnya). „Голос Волині”, Житомир 1942, 6 червня („Holos Volyni”, Zhytomyr 1942, 6 chervnya). 
„Голос Волині”, Житомир 1943, 3 мипня („Holos Volyni”, Zhytomyr 1943, 3 lypnya).

„Голос Волині”, Житомир 1943, 9 мипня („Holos Volyni”, Zhytomyr 1943, 9 lypnya).

„Голос Волині”, Житомир 1943, 17 мипня („Holos Volyni”, Zhytomyr 1943, 17 lypnya).

„Голос Волині”, Житомир 1943, 4 вересня („Holos Volyni”, Zhytomyr 1943, 4 veresnya).

„Голос Волині”, Житомир 1943, 26 жовтня („Holos Volyni”, Zhytomyr 1943, 26 zhovtnya).

„Нова доба”, Бердичів 1941, 5 грудня („Nova doba”, Berdychiv 1941, 5 hrudnya).

„Нова доба”, Бердичів 1942, 4 березня („Nova doba”, Berdychiv 1942, 4 bereznya).

„Омевські вісті”, Омевськ 1943, 17 мипня („Olevs'ki visti”, Olevs’k 1943, 17 lypnya).

„Овручські вісті”, Овруч 1943, 11 вересня („Ovruchs'ki visti”, Ovruch 1943, 11 veresnya). „Українське слово”, Житомир 1941, 17 серпня („Ukrayins'ke slovo”, Zhytomyr 1941, 17 serpnya).

„Звягельське слово”, Звягель 1943, 10 мипня („Zvyahel's'ke slovo”, Zvyahel' 1943, 10 lypnya).

\section{Opracowania}

Мокрицький Г., Вулиці Житомира, Житомир 2007 (Mokryts'kyy H., Vulytsi Zhytomyra, Zhytomyr 2007).

Михаймюк М., Німещька пропаганда в Україні, [в:] Україна в Аругій світовій війні. Погляд з XXI cm. Історичні нариси. Кн. 1, ред. О. Аисенко, Київ 2010, с. 644-658 (Mykhaylyuk M., Nimets'kapropahandav Ukrayini, [w:] Ukrayinav Drubiysvitoviyviyni. Pohlyad zXXI st. Istorychni narysy. Kn. 1., red. O. Lysenko, Kyyiv 2010, s. 644-658).

Рекотов П., Органи управління на окупованій території України (1941-1944рр.), „Український історичний журнал” (1997), № 3, с. 90-101 (Rekotov P., Orhany upravlinnya na okupovaniy terytoriyi Ukrayiny (1941-1944 rr.), „Ukrayins'kyy istorychnyy zhurnal" 1997, nr 3, s. 90-101).

Lower W., Nazi Empire Building and the Holocaust in Ukraine, Chapel Hill 2005.

Sergey Stelnikovich (Сергей Стельникович)

\section{THE URBAN POPULATION AND NAZI PROPAGANDA DURING THE WORLD WAR II (ON THE EXAMPLE OF THE CITIES OF ZHYTOMYR REGION)}

Summary. The population of the Nazi-occupied territory of Ukraine was systematically influenced by propaganda. Nazi propaganda was aimed at the urban population of the Zhytomyr region. Zhytomyr region occupied one of the central places in the occupation policy 
of Germany. Heinrich Himmler's quarter was located near Zhytomyr, and the German colonies Hegewald and Forsterstadt were established here. Zhytomyr region had a multi-ethnic population and was active in the resistance movement. Newspapers, radio, newsreels, and leaflets were the main means of Nazi propaganda among the urban population of the Zhytomyr region. The Nazis carried out anti-Soviet propaganda among the population of the region's cities. This propaganda was carried out by such methods as the destruction of monuments and changing the names of individual settlements. Streets, squares and alleys began to change in cities. In the second half of 1943 the main method of propaganda was the exhumation of the victims of the Vinnytsia NKVD. Anti-Jewish propaganda occupied a special place. The reason is that some cities in the Zhytomyr region, including Berdychiv, were centers of Jewish culture in the pre-war period. Anti-Jewish propaganda was systemic in nature and combined with anti-Soviet propaganda campaigns. An important direction of Nazi propaganda during the World War II among the urban population of the region were campaigns aimed at supporting the occupation policy and the occupation order.

Keywords: Zhytomyr region, Nazi occupation, propaganda, urban population, newspaper 